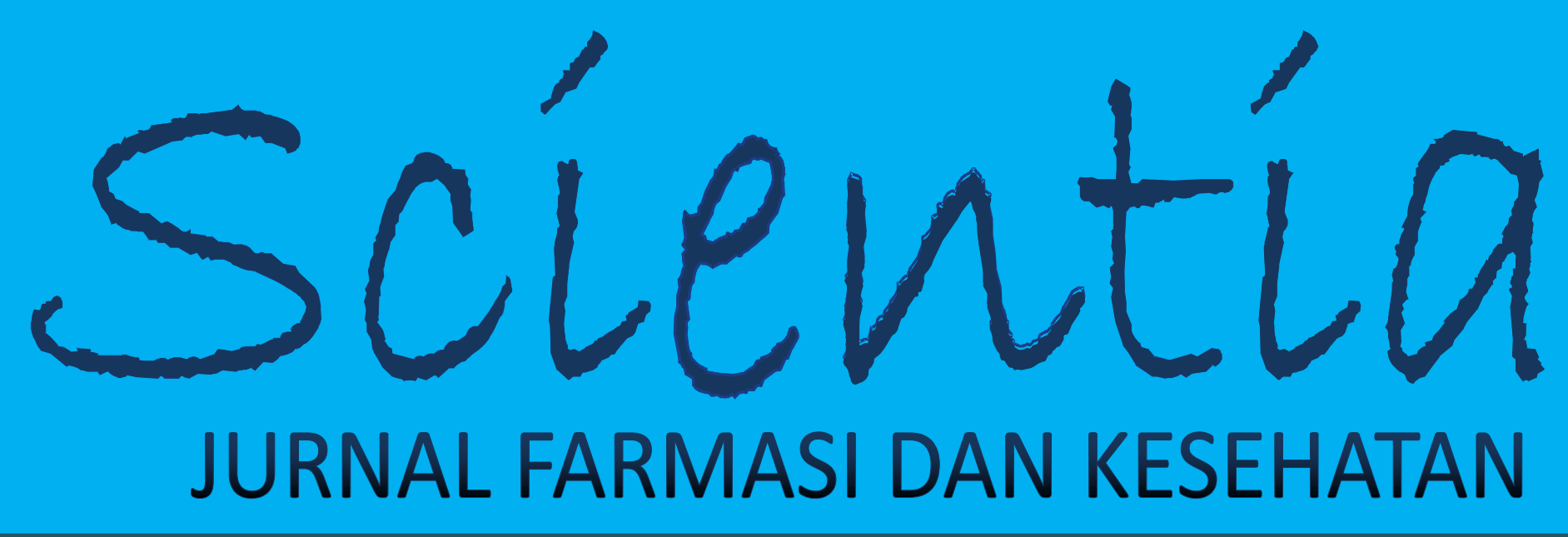

ISSN : 2087-5045

Volume 5, Nomor 2, Agustus 2015

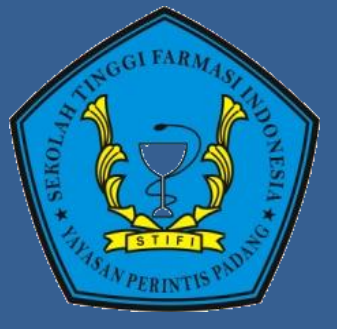

Diterbitkan oleh:

Sekolah Tinggi Farmasi Indonesia (STIFI) Yayasan Perintis Padang 


\section{SCIENTIA \\ JURNAL FARMASI DAN KESEHATAN}

TERBIT DUA KALI SETAHUN

SETIAP BULAN FEBRUARI DAN AGUSTUS

\section{DEWAN REDAKSI}

\section{Penanggung Jawab :}

Prof. H. Syahriar Harun, Apt

\section{Pemimpin Umum :}

DR.H.M. Husni Mukhtar,MS, DEA, Apt

\section{Redaktur Pelaksana :}

Verawati, M.Farm, Apt

Eka Fitrianda, M.Farm, Apt

Putri Ramadheni, M.Farm, Apt

\section{Sekretariat :}

Afdhil Arel, M.Farm, Apt

Khairul

\section{Dewan Penyunting :}

Prof.H. Syahriar Harun, Apt

Prof.DR.H. Amri Bakhtiar,MS,DESS, Apt

Prof.DR.H. Almahdy, MS, Apt

DR.H.M. Husni Mukhtar, MS, DEA, Apt

DR. H. Yufri Aldi, MSi, Apt

Drs. B.A. Martinus, MSi

Hj. Fifi Harmely, M.Farm, Apt

Farida Rahim, M.Farm, Apt

Revi Yenti, M.Si, Apt

Verawati, M.Farm, Apt

Ria Afrianti, M.Farm, Apt

Eka Fitrianda, M.Farm, Apt

Mimi Aria, M.Farm, Apt

Dira, MSc, Apt

\section{Penerbit :}

Sekolah Tinggi Farmasi Indonesia (STIFI) Perintis Padang

ISSN : 2087-5045

\section{Alamat Redaksi/Tata Usaha :}

STIFI Perintis Padang

Jl. Adinegoro Km. 17 Simp. Kalumpang Lubuk Buaya Padang

Telp. (0751)482171, Fax. (0751)484522

e-mail : stifpadang@gmail.com

website : www.stifi-padang.ac.id

Jurnal online : www.jurnalscientia.org 


\section{DAFT A R IS I}

UJI AKTIFITAS ANTIJAMUR EKSTRAK GAMBIR

(UncariagambirRoxb) TERHADAP Candida albicans SECARA IN VITRO

$62-68$

Suraini, Chairani dan Enlita

PENGUJIAN AKTIVITAS ANTIOKSIDAN DAN TABIR SURYA

EKSTRAK ETANOL KULIT BUAH NAGA SUPER MERAH

(Hylocereus costaricensis (F.A.C. Weber) Britton \& Rose)

Widyastuti, Rizqi Ikhwanda Fratama dan Ade Seprialdi

EFEK ANTIINFLAMASI DARI EKSTRAK KULIT BUAH DURIAN

(Durio zibethinus Murray) TERHADAP TIKUS PUTIH JANTAN

Masayu Azizah dan Fitriani

RASIONALITAS PENGGUNAAN ANTIBIOTIKA PADA PENYAKIT ISPA

DI PUSKESMAS KUAMANG KUNING I KABUPATEN BUNGO

Sanubari Rela Tobat, M. Husni Mukhtar dan Ida Hot Duma Pakpahan

UJI EFEK ANTIINFLAMASI FRAKSI DAUN PILADANG

84-91

(Solenostemon scutellarioides (L.) Codd) TERHADAP MENCIT PUTIH BETINA

Mimi Aria, Verawati, Afdhil Arel dan Monika

AKTIVITAS BEBERAPA SUBFRAKSI HERBA MENIRAN (Phyllanthusniruri Linn.)

92-96 TERHADAP AKTIVITAS DAN KAPASITAS FAGOSITOSIS MAKROFAG

Yufri Aldi, Frisky Novelin dan Dian Handayani

UJI AKTIVITAS ANTIHIPERGLIKEMIA EKSTRAK ETANOL DAUN SISIK

NAGA (Drymoglossum piloseillodes (L.) C. Presl) ) PADA MENCIT PUTIH JANTAN

YANG DIINDUKSI STREPTOZOCIN

Ria Afrianti, Lola Azyenela dan Devi Umar Yani

PENGARUH KONSENTRASI GELATIN DALAM FORMULASI PERMEN JELI

PENGHILANG BAU MULUT dari MINYAK ATSIRI BUAH KAPULAGA

103-107

(AmomumcompactumSol. Ex Maton)

Chris Deviarny, Friardi dan Mexsi Mutia Rissa

PERBANDINGAN PENGARUH PEMBERIAN EKSTRAK ETANOL Defatting

DAN EKSTRAK ETANOL DAUN BENALU KOPI Scurrula ferruginea (Jack) DANSER TERHADAP KADAR GLUKOSA DARAH MENCIT PUTIH JANTAN

Dwisari Dillasamola, Surya Dharma dan Nurul Qalbi Al Khaira

PENGARUH BEBERAPA JENIS LARUTAN ASAM PADA PEMBUATAN

114-121

GELATIN DARI KULIT IKAN SEPAT RAWA (Trichogaster trichopterus)

KERING SEBAGAI GELATIN ALTERNATIF

Revi Yenti, Dedi Nofiandi dan Rosmaini

AKTIVITAS ANTI DIABETES DAN ANTI DISLIPIDEMIA DARI KOMBINASI

122-127

EKSTRAK BUAH RIMBANG (SolanumtorvumSwartz) DAN RIMPANG

TEMULAWAK (Curcuma xanthorriza Roxb) PADA MENCIT DIABETES YANG

DIINDUKSI ALOKSAN

Eka Fitrianda dan Erniwati 


\title{
AKTIVITAS BEBERAPA SUBFRAKSI HERBA MENIRAN (Phyllanthusniruri Linn.) TERHADAP AKTIVITAS DAN KAPASITAS FAGOSITOSIS MAKROFAG
}

\author{
Yufri Aldi, Frisky Novelin dan Dian Handayani \\ Fakultas Farmasi Universitas Andalas \\ Email :yufrialdi@gmail.com
}

\begin{abstract}
Study about the activity of some subfraction of ethyl acetate extract of herba meniran have been done. The parameters determined were the phagocytosis activity and capacity of peritoneal macrophages of male mice (Mus musculus) in vivoinduced by Staphylococcus aureus. Subfraction of 1,2,3,4,5,6,7, and 8 were tested at a dose of $100 \mathrm{mg} / \mathrm{kg}$ and $1 \%$ Tween 80 was used as a control, all were given orally for 7 days. Activity and capacity of phagocytosis were calculated on the $8^{\text {th }}$ day after the number of cells blood leukocytes counted from tail blood and suspension of Staphylococcus aureus injected intraperitoneally. Test result showed that subfraction of 1,2,3,4,5,6,7, and 8 at dose 100 $\mathrm{mg} / \mathrm{kg}$ bb did not affect the number of leukocyte. Whereas phagocytosis activity increased significantly $(P<0.05)$, highest activity showed by subfraction 4 , which was $96 \%$ compared to $62.58 \%$ control, and the capacity of phagocytosis increased significantly $(P<0.01)$, highest capacity was showed by the subfraction 4 which was $109.50 \%$ compared to control of $77.83 \%$.
\end{abstract}

Keywords : subfraction, herba meniran, activity and capacity of phagocytosis

\section{PENDAHULUAN}

Tubuh manusia terdiri dari berbagai macam organ yang membentuk sistem organ dan sistem fungsional tubuh yang masingmasing bekerja sama dalam satu kesatuan sistem tubuh kita. Di antara sistem tersebut terdapat sistem pertahanan tubuh atau disebut juga dengan sistem imun. Sistem ini bertanggung jawab melindungi tubuh dari benda-benda asing yang masuk sehingga fungsi tubuh tidak terganggu (Janeway, 2001).

Mekanisme pertahanan tubuh dapat ditingkatkan dengan senyawa tertentu yang bersifat imunomodulator. Imunomodulator secara umum didefenisikan sebagai senyawa yang dapat meningkatkan mekanisme pertahanan tubuh baik secara spesifik maupun non spesifik baik mekanisme pertahanan seluler maupun humoral (Kresno, 2003).

Meniran adalah herba yang berasal dari genus Phyllanthus dengan nama ilmiah Phylanthus niruri Linn. Tumbuhan ini kaya akan berbagai kandungan kimia, antara lain : lignan (filantin, hipofilantin, nirantin, lintetratin), flavonoid (quersetin dan rutin), dll (Wibowo, 2009).
Dalam kaitannya dengan sistem imun, pemberian ekstrak Phyllanthus niruri Linn dapat meningkatkan aktivitas dan fungsi beberapa komponen imunitas nonspesifik maupun spesifik, baik humoral maupun selular. Hal ini dapat dilihat dari berbagai penelitian yang menyatakan bahwa tanaman tersebut dapat meningkatkan respon imun nonspesifik berupa peningkatan kemotaksis makrofag, kemotaksis neutrofil, sitotoksisitas sel NK (Natural Killer) serta aktivitas hemolisis komplemen. Ekstrak Phyllanthus niruri Linn juga meningkatkan poliferasi sel limfosit T, meningkatkan sekresi Tumor Necrosis Faktor- $\alpha$ (TNF $\alpha)$ dan Interleukin4(IL-4), menurunkan sekresi IL-2 dan IL-10. Terhadap imunitas humoral, tanaman ini dapat meningkatkan produksi imunoglobulin $M$ (IgM) serta IgG (Sjahrurachman, 2004). Subfraksi etil asetat dari herba meniran (Phyllanthus niruri Linn.) dapat meningkatkan poduksi antibodi dan peningkatan produksi antibodi yang paling tinggi adalah subfraksi nheksan : etil asetat (4:1)(Farhan, 2012). Subfraksi dari tumbuhan ini juga memiliki aktivitas imunostimulan pada mencit putih jantan dengan metode uji Carbon Clearance dan dapat menghambat reaksi hipersensitivitas 
pada mencit yang di induksi dengan albumin (Mahyuddin, 2013).

Makrofag adalah sel fagosit yang berasal dari sel monosit yang telah dewasa. Ukurannya 10 - $30 \mathrm{~mm}$ dan merupakan sel yang memiliki umur panjang. Sel ini memilik dua fungsi yaitu menghancurkan antigen dan menyajikan antigen kepada sel limfosit $\mathrm{T}$, yang dikenal dengan sistim Antigen Presenting Cell (APC). Ini merupakan tahap awal terjadinya respon imun selular dan humoral. Makrofag yang telah menelan antigen juga memproduksi sejumlah sitokin, yaitu protein penting untuk respon imun seperti IL-1, IL-2, IL-6, TNF $\alpha$. Sistem ini akan memberikan efek pada sel-sel efektor termasuk sel makrofag itu sendiri $(15,16,17,18)$. Pada penelitian ini dicoba untuk menguji aktifitas subfraksi dari herba meniran terhadap aktivitas dan kapasitas makrofag.

\section{METODE PENELITIAN}

Penelitian ini bersifat eksperimental (Experimental Research), karena belum ada yang pernah meneliti tentang pengaruh pemberian subfraksi ekstrak etil asetat herba meniran terhadap aktivitas fagositosis.

\section{Alat \\ Kertas saring, rotary evaporator, alat kromatografi kolom, vial, bejana (chamber), dan plat KLT, desikator, pipet tetes, lampu UV $245 \mathrm{~nm}$, gelas ukur, timbangan hewan, spatel, jarum oral, timbangan analitik, wadah (botol), mikroskop, lumpang dan stamfer, kaca objek, gunting bedah, sarung tangan, masker.}

\section{Bahan}

Bahan yang digunakan adalah herba meniran (Phyllantus niruri Linn), n-heksan, etil asetat, metanol, air suling, Stapylococuc aureus, nutrient agar (NA), nutrien brooth (NB), jarum ose, $\mathrm{NaCl}$ fisiologis, tween 80 , pewarna Giemsa, mencit putih jantan dengan berat 20-40 gram

\section{Cara Kerja}

\section{Pengambilan sampel}

Herba meniran (Phyllantus niruri Linn) diambil di Simpang Tanjung, Padang Pariaman Sumatera Barat.

\section{Isolasi subfraksi herba meniran}

Sebanyak $3 \mathrm{~kg}$ sampel kering meniran yang telah bersih dan dirajang halus, dimaserasi menggunakan etil asetat dalam botol coklat selama 5 hari sambil sesekali di kocok. Setelah 5 hari perendaman, diambil maseratnya dengan cara disaring, lakukan dengan 3 kali pengulangan. Gabungan maserat diuapkan secara in vacuo sehingga diperoleh ekstrak kental.

Ekstrak kental yang telah dipreadsorpsi terlebih dahulu dipisahkan dengan metode kromatografi kolom flash menggunakan fasa gerak yang tingkat kepolarannya ditingkatkan (step gradient polarity). Fasa gerak yang digunakan terdiri dari pelarut heksan, dan etil asetat baik dalam bentuk tunggal maupun kombinasi.

\section{Persiapan Hewan Percobaan}

Hewan percobaan yang digunakan adalah mencit putih jantan sebanyak 36 ekor yang berumur 2-3 bulan dengan berat badan 20-25 gram dan belum pernah mengalami perlakuan terhadap obat. Sebelum digunakan sebagai hewan percobaan, semua mencit diadaptasi terlebih dahulu selama satu minggu untuk penyesuaian lingkungan, mengontrol kesehatan dan berat badan serta menyeragamkan makanan.

\section{Penentuan dosis}

Dosis subfraksi yang digunakan untuk uji ini adalah $100 \mathrm{mg} / \mathrm{kgbb}$.

\section{Pembuatan suspensi subfraksi}

Larutan uji dibuat dalam Tween $801 \%$, Subfraksi ditimbang sebanyak $20 \mathrm{mg}$ tambahkan tween 80 sebanyak 2 tetes. Gerus homogen dan kemudian volumenya dicukupkan sampai $2 \mathrm{ml}$ dengan aquadest.

\section{Kultur Staphylococus aureus}

Staphylococus aureus (SA) dibiakkan pada nutrient agar (NA) miring. Dari satu ose kultur SA diinokulasi ke dalam media NA miring, setelah itu diinkubasi pada suhu $37^{\circ} \mathrm{C}$ selama 24 jam di dalam inkubator. Staphylococus aureus yang tumbuh pada NA miring dipindahkan ke dalam nutrient brooth (NB), diinkubasi selama 24 jam pada suhu $37^{\circ} \mathrm{C}$. Kemudian disentrifugasi dengan 2500 rpm selam 25 menit lalu terbentuk pelet dan disuspensikan dengan $\mathrm{NaCl}$ fisiologis (Boerlin, 2003). 


\section{Pemberian subfraksi}

Mencit dibagi kedalam 9 kelompok, yaitu kelompok pemberian kontrol Tween 80, n-heksan $100 \%$, heksan:etil (19:1), heksan:etil (9:1), heksan:etil (4:1), heksan:etil (2:1), heksan:etil (1:1), heksan:etil (1:4), Etil asetat $100 \%$. Volume filantin yang diberikan $0,3 \mathrm{ml}$ untuk mencit 30 gram. Masing-masing kelompok dicobakan pada 4 ekor mencit. Pada hari pertama hingga ketujuh, mencit diberikan zat uji dan kontrol per oral.

\section{Analisis fagositosis makrofag}

Pada hari kedelapan, mencit pada masing-masing kelompok diinfeksi dengan bakteri SA dalam suspensi $0,5 \mathrm{ml} \mathrm{NaCl} 0,9 \%$ yang disuntikkan intra peritonial (IP), kemudian dibiarkan selama 1 jam. Mencit dibunuh dan dibedah, kemudian tambahkan heparin pada cairan peritoneal. Cairan peritoneal diambil dengan menggunakan spuit $1 \mathrm{ml}$. Cairan peritoneal tersebut dibuat preprarat apus dan difiksasi dengan metanol absolut selama 5 menit, diwarnai dengan Giemsa yang telah diencerkan dengan air suling 20 kalinya, didiamkan selama 20 menit, dibilas dengan air dan dikeringkan. Preparat dilihat dibawah mikroskop cahaya pada perbesaran 1000 kali dengan minyak emersi. Aktivitas dan kapasitas fagositosis sel makrofag dihitung. Aktivitas atau indeks fagositosis ditetapkan berdasarkan persentase jumlah makrofag yan dari 100 sel fagosit (makrofag) yang aktif. Sedangkan kapasitas fagositosis ditetapkan berdasarkan jumlah SA yang difagosit oleh 100 fagosit aktif (Boerlin, 2003).

\section{HASIL DAN PEMBAHASAN}

$10 \mathrm{~kg}$ herba meniran segar diperoleh 3 kg sampel kering dan hasil ektraksi diperoleh 178 g ekstrak kental. Dari 178 g ekstrak kental mengunakan kromatografi kolom flash di dapatkan subfraksi 1 (n- heksan) sebanyak 89,5 g, subfraksi 2 (n-heksan : etil asetat (19:1)) 8,5 g, sub fraksi 3 (n-heksan : etil asetat (9:1) $4 \mathrm{~g}$, subfraksi 4(n-heksan : etil asetat (4:1) 4,2 g, subfraksi 5 (n-heksan : etil asetat (2:1) 7,6 g, subfraksi 6 (n-heksan : etil asetat (1:1) 9,7 g, sub fraksi 7 (n-heksan : etil asetat (1:4) $8,3 \mathrm{~g}$ dan subfraksi 8 (etil asetat) 4,5 g.
Pemeriksaan subfraksi meliputi pemerian dan kelarutan dapat dilihat Tabel 1.

Tabel 1. Hasil pemeriksaan subfraksi dari ekstrak etil asetat herba meniran

\begin{tabular}{|c|c|c|}
\hline No & Pemeriksaan & Pengamatan \\
\hline \multirow[t]{5}{*}{1.} & Pemerian & \\
\hline & -Warna & Hijau tua \\
\hline & -Bau & $\begin{array}{l}\text { Menyengat dan } \\
\text { taiam }\end{array}$ \\
\hline & -Rasa & Sangat pahit \\
\hline & & Praktis tidak \\
\hline 2. & Kelarutan & larut dalam air \\
\hline
\end{tabular}

Subfraksi yang digunakan dibuat sediaan uji dalam bentuk suspensi karena subfraksi sukar larut dalam cairan pembawa, maka larutan uji dibuat dengan menambahkan suspending agent tween 80 sehingga dihasilkan campuran yang homogen. Suspending agent ini berfungsi menurunkan tegangan permukaan bahan dengan air (Sjahrurachman, 2004).

Mencit dikelompokkan menjadi 9 kelompok yang masing-masing diberi perlakuan yang berbeda. Dalam penelitian ini dilihat efek subfraksi meniran terhadap peningkatan aktivitas dan kapasitas fagositosis sel makrofag.

Subfraksi meniran diberikan selama 7 hari berturut-turut dan pada hari kedelapan disuntikkan Staphylococus aureus (SA) secara intra peritonial. Sel makrofag akan menangkap antigen dalam hal ini adalah SA. SA agak sukar dibunuh karena menghasilkan beberapa enzim seperti streptolisin, hemolisin, karetenoid dan katalase yang menetralkan singlet oksigen dan superoksida sehingga pengamatan lebih baik.

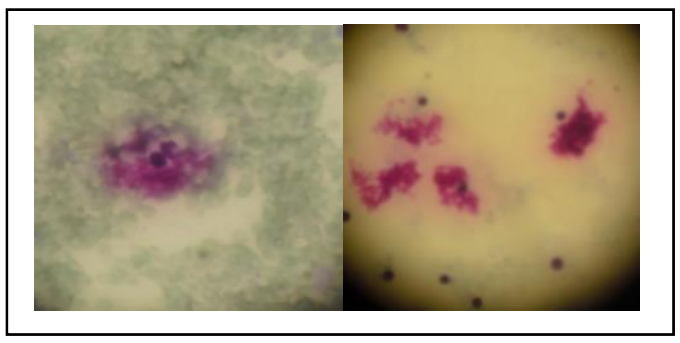

Gambar 1. Gambar sel makrofag peritoneal mencit. 
Aktivitas dan kapasitas fagositosis dilakukan pada makrofag peritonial yang bersifat fagosit dan kemotaksis (Stvrtinova, 1995). Hasil pemeriksaan aktivitas fagositosis dapat dilihat Tabel 2.

Tabel 2. Hasil persentase aktivitas fagositosis dari makrofag peritonial mencit putih jantan.

\begin{tabular}{|clc|}
\hline No & Kelompok Uji & $\begin{array}{c}\text { Aktivitas } \\
\text { fagositosis }(\mathbf{\%}) ; \\
(\mathbf{x} \pm \mathbf{S D})\end{array}$ \\
\hline $\mathbf{1}$ & Kontrol (Tween 80) & $62,58 \pm 3,21$ \\
\hline $\mathbf{2}$ & Subfraksi 1 & $63,5 \pm 2,35$ \\
\hline $\mathbf{3}$ & Subfraksi 2 & $72,17 \pm 4,15$ \\
\hline $\mathbf{4}$ & Subfraksi 3 & $81,67 \pm 4,04$ \\
\hline $\mathbf{5}$ & Subfraksi 4 & $96,00 \pm 0,99$ \\
\hline $\mathbf{6}$ & Subfraksi 5 & $84,99 \pm 6,28$ \\
\hline $\mathbf{7}$ & Subfraksi 6 & $73,00 \pm 4,77$ \\
\hline $\mathbf{8}$ & Subfraksi 7 & $67,75 \pm 8,31$ \\
\hline $\mathbf{9}$ & Subfraksi 8 & $69,75 \pm 2,28$ \\
\hline
\end{tabular}

Hasil uji stastistik analisa varian satu arah dan dilanjutkan uji berjarak Duncan didapatkan hasil aktivitas fagositosis sel makrofag sangat signifikan $(\mathrm{P}<0,05)$ terhadap kontrol. Aktivitas fagositosis sel makrofag berbeda nyata antara kontrol dan pemberian beberapa fraksi Aktivitas fagositosis makrofag yang terbesar diberikan oleh fraksi 4. Hasil dari pemeriksaan kapasitas fagositosis sel makrofag setelah pemberian subfraksi dapat dilihat Tabel 3.

Tabel 3. Hasil pemeriksaan kapasitas sel makrofag dari makrofag peritonial mencit putih jantan.

\begin{tabular}{|llc|}
\hline No & Kelompok Uji & $\begin{array}{c}\text { Kapasitas sel } \\
\text { makrofag }(\mathbf{x} \pm \text { SD) }\end{array}$ \\
\hline $\mathbf{1}$ & Kontrol (Tween 80 ) & $77,83 \pm 14,03$ \\
\hline $\mathbf{2}$ & Subfraksi 1 & $81,99 \pm 2,05$ \\
\hline $\mathbf{3}$ & Subfraksi 2 & $89,92 \pm 5,31$ \\
\hline $\mathbf{4}$ & Subfraksi 3 & $96,00 \pm 2,49$ \\
\hline $\mathbf{5}$ & Subfraksi 4 & $109 \pm 13,43$ \\
\hline $\mathbf{6}$ & Subfraksi 5 & $107,50 \pm 4,82$ \\
\hline $\mathbf{7}$ & Subfraksi 6 & $85,42 \pm 3,93$ \\
\hline $\mathbf{8}$ & Subfraksi 7 & $81,92 \pm 7,66$ \\
\hline $\mathbf{9}$ & Subfraksi 8 & $81,24 \pm 3,61$ \\
\hline
\end{tabular}

Setelah dilakukan analisa varian satu arah ternyata Kapasitas fagositosis sel makrofag sangat berbeda nyata dan pemberian beberapa subfraksi. Kapasitas fagositosis tertinggi diberikan oleh fraksi 4 yaitu fraksi nheksan:etil asetat (4:1).

\section{KESIMPULAN DAN SARAN}

\section{Kesimpulan}

Hasil penelitian yang telah dilakuakan, dapat diambil kesimpulan sebagai berikut :

1. Pemberian subfraksi dari ekstrak etil asetat pada dosis $100 \mathrm{mg} / \mathrm{kgBB}$ dapat meningkatkan indeks fagositosis dan kapasitas makrofag.

2. Aktivitas dan kapasitas fagositosis yang paling tinggi diberikan oleh subfraksi 4 yaitu n-heksan : etil asetat $(4: 1)$.

\section{Saran}

Disarankan pada peneliti selanjutnya untuk meneliti subfraksi dari ekstrak etil asetat, terhadap sitem imun dan menentukan senyawa apa yang terdapat didalam beberapa subfraksi tersebut.

\section{DAFTAR PUSTAKA}

Boerlin P, Kunhert P, Hussy ED and Schaelliubaum M.,2003, Methods for identifications of Stapylococcus aureus isolated in cases of bovine mastitis. Journal of Clinical Microbiologi, 767771.

Farhan, Aldi Y dan A Bakhtiar, 2012, Uji Aktivitas Beberapa Subfraksi Etil Asetat dari Herba Meniran (Phyllanthus niruri Linn.) Terhadap Titer Antibodi dan Jumlah Sel Leukosit pada Mencit Putih Jantan, Skripsi S1, Fakultas Farmasi Universitas Andalas Padang.

Janeway CA, 2001, Immunobiology: The immune System in Health and Disease, Marion Morrow, Rory MacDonald Garland Publishing, New York.

Kresno SB, 2003, Imunologi: diagnosis dan prosedur laboratorium, Edisi 4, Fakultas Kedokteran Universitas Indonesia, Jakarta,.

Mahyuddin, Y Aldi dan D Handayani, 2013, Uji Aktivitas Beberapa Fraksi Dari Meniran (Phyllanthus Niruri Linn.) Terhadap Reaksi Hipersensitivitas Kutan Aktif, JSTF, 2013. Vol.18 No.1. 
Sjahrurachman A, Sukmana, N, Setiati S. Munazir Z, Rubiana H, Nelwan, Lesmana dan Dianiati, 2004, Pemberian Terapi Imunomodulator Herbal. Jurnal HTA Indonesia, 37-40.

Stvrtinova V, Jakubovsky J and Hulin I, 1995, Inflammation and Fever, Computer Based Learning Unit, University of Leeds.

Wibowo AS, 2009, Efek Imunostimulan Ekstrak Meniran (Phyllanthus niruri L) secara in vivo pada Tikus (Immunostimulan Effect of Extract in vivo on Rat). Jurnal Bahan Alam Indonesia. 
SCIENTIA VOL. 5 NO. 2, AGUSTUS 2015 